International Journal of Life Sciences
Available online at www.sciencescholar.us
Vol. 4 No. 1, April 2020, pages: 1-7
e-ISSN: 2550-6986, p-ISSN: 2550-6994
https://doi.org/10.29332/ijls.v4n1.386

\title{
Social Implications of Biomass-Based Energy Generation in the Technical University of Manabí, Ecuador
}

\author{
C) Crossark
Carlos Alejandro Bowen Quiroz a, María Rodríguez Gámez b, Ciaddys Gina Rodriguez Borges c, Jesús Alberto Pérez Rodríguez ${ }^{\mathrm{d}}$

Manuscript submitted: 09 November 2019 Manuscript revised: 18 December 2019, Accepted for publication: 27 January 2020

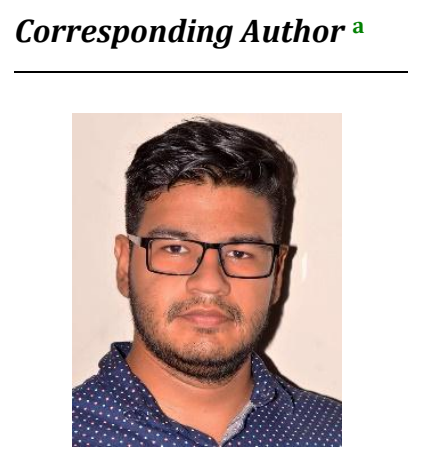

Keywords

biomass;

energy;

management;

renewable;

survey;

\begin{abstract}
Biomass as an energy source will play a fundamental role in the coming years. The versatility of biomass-based generation systems makes them attractive projects at any scale. At the Technical University of Manabí, large quantities of organic and forest residues are generated, which can be used to generate energy. A survey was applied to determine the level of knowledge of the university community on issues related to the energy use of biomass and solid waste management. The results show that there is a knowledge gap in the community and it will be necessary, if such a system is implemented, to train all those involved in the generation, handling and disposal of solid waste to strengthen the proposal.
\end{abstract}

International Journal of Life Sciences (C) 2020.

This is an open access article under the CC BY-NC-ND license (https://creativecommons.org/licenses/by-nc-nd/4.0/).

\section{Contents}

Abstract

1 Introduction

2 Materials and Methods

3 Results and Discussions

4 Conclusion Acknowledgments

\footnotetext{
a Universidad Técnica de Manabí, Portoviejo, Ecuador

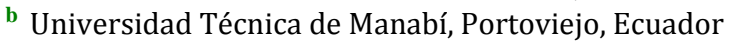

${ }^{c}$ Universidad Técnica de Manabí, Portoviejo, Ecuador

${ }^{\text {d }}$ Universidad Técnica de Manabí, Portoviejo, Ecuador
} 


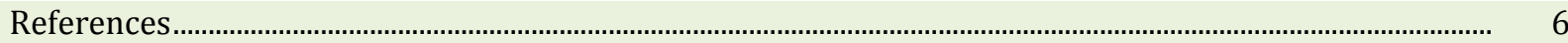

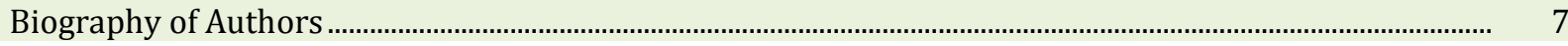

\section{Introduction}

In the future, power generation systems must be renewable, sustainable, efficient and safe (Chum \& Overend, 2001). In this sense, biomass as a renewable energy source will have an important role in the next years. In general, photosynthetic derivate, animal and plant origin organic matter are called biomass; also, any biomass-based fuel is called biofuel (Serna et al., 2011). Biomass conversion technologies into biofuels can be classified by different parameters. For instance, for dry biomass, thermochemical processes are recommended, which often derivates into liquid biofuels; and for wet biomass, biochemical processes are recommended, which derivates into biogas (Serrano et al., 2017; Herout et al., 2011).

Anaerobic digestion is a natural process, taking place in the absence of oxygen. Involves organic matter decomposition by bacteria process which generates a rich in energy biogas and a rich in nutrients digest (Duerr et al., 2007; Perez et al., 2017). Biogas chemical composition consists of 50-85\% methane ( $\mathrm{CH}_{4}$ ); carbon dioxide $\left(\mathrm{CO}_{2}\right)$, hydrogen $\left(\mathrm{H}_{2}\right)$, nitrogen $\left(\mathrm{N}_{2}\right)$ and traces of hydrogen sulfide $\left(\mathrm{H}_{2} \mathrm{~S}\right)$ and ammonia $\left(\mathrm{NH}_{3}\right)$ from the rest (Herout et al., 2011). Whereas $\mathrm{CH}_{4}$ would be released to the atmosphere in natural conditions, and that methane GPW is 28 times greater than $\mathrm{CO}_{2}$ (IPCC, 2014), power generation by anaerobic digestion not only displace conventional energy sources, it also helps to reduce greenhouse gasses emissions. Also, the successful deployment of a biomass-based power generation system brings social, economic and environmental benefits (Duerr et al., 2007).

Ecuador has implemented some politics in order to satisfy energy demand increase, such as Energy Matrix Change, giving way to renewable energies as a primary energy source (SENPLADES, 2017). By September $2019,75,3 \%$ of power generation in Ecuador was supplied by renewable sources, particularly hydropower, with 73,5\% and biomass with 1,2\% (ARCE, 2019). There is only one biomass-based power plant (Thermochemical) in Quito, with a power of $5 \mathrm{MW}$, enough to provide energy to 25000 houses (Quito Municipality, 2017). Moreover, in the Technical University of Manabí (UTM), the generation of organic and forest residues is considerable, nevertheless, no use of biomass is made from green areas and food waste. These are disposed of in the municipal landfill, in spite of the economic and environmental implications that this entails. As Ivan et al. (2015), explains the final disposal of waste in uncontrolled sites is a serious environmental problem that affects the landscape, local flora and fauna, water bodies, as well as the latent presence of sources of pollution that threaten human life.

Nevertheless, biomass has a promising future as a primary source of energy in Ecuador, mainly because: a) it is a renewable resource, b) it is environmentally friendly since its net rate of CO2 emissions is annulled and c) its economic potential in the face of the price of conventional energies (Serrano et al., 2017; Cedeno et al., 2017).

This study aims to know the level of knowledge of the UTM community in the use of organic solid waste for energy generation subjects. The first approach through a survey will establish priority groups, in order to focus training efforts to these on issues of renewable energy, management and use of solid waste and energy efficiency.

\section{Materials and Methods}

The data collection method was the survey. The UTM community was surveyed using a sample of 1067 people, obtained as described by Spiegel \& Stephens (2007), with 95\% reliability and a maximum permissible error of 3\%. The UTM community was divided into four groups: lecturers, students, janitors, and administrative staff. Based on the time spent on campus and waste generation capacity, the number of respondents for each group was determined. 


\section{Results and Discussions}

The survey was carried out successfully. The results of each are presented below.

Question 1: Do you consider it possible to generate electricity from waste generated by the university?

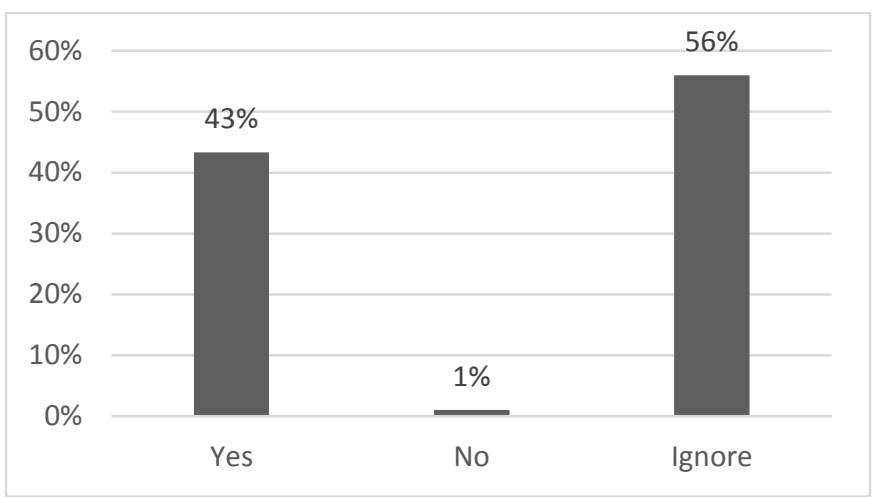

Figure 1. Results of question 1

Figure 1 shows that 43\% (462 people) answered yes and less than 1\% (one person) answered negatively. According to Carneiro \& Ferreira (2012), the university's ability to generate energy from its waste depends on the community's consumption patterns and the organic fraction of total waste production. In this sense, it will be necessary to determine technical aspects of solid waste generation within the university, such as consumption patterns, amount of waste generated, organic fraction of this waste, composition, humidity, C:N ratio, among others. However, the most striking aspect of this result is the high percentage of ignorance of the subject $(56 \%, 604$ people).

Question 2: Do you consider the generation of electricity from organic waste to be feasible and environmentally friendly?

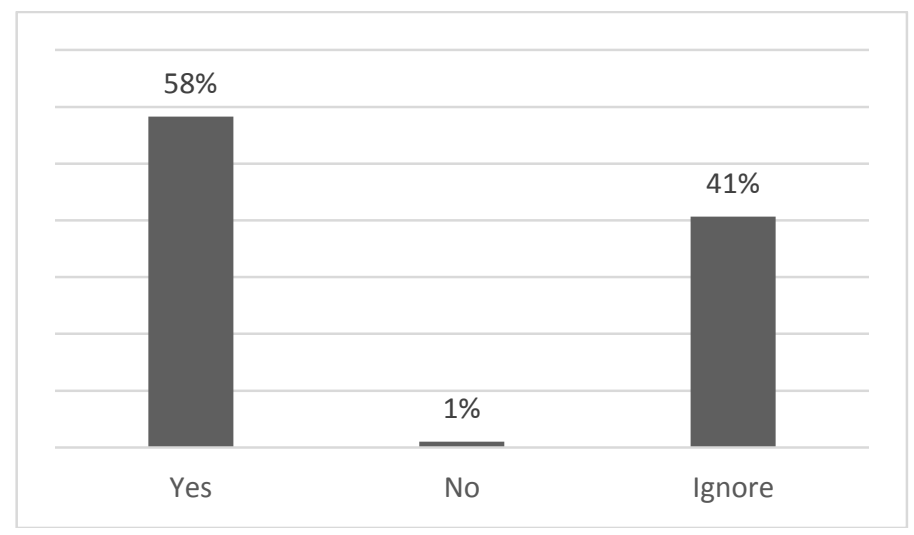

Figure 2. Results of question 2

As shown in Figure 2, 58\% of respondents (622) answered in the affirmative. Some studies, such as Ivan et al. (2015), show that it is possible to obtain economic benefits from producing biogas from solid organic waste, obtaining approximately 17-39 USD $\mathrm{t}^{-1}$. Considering that the approximate cost of disposal per ton of waste is USD 8.89 (Chong et al., 2005) and that estimates of benefits, even in the most pessimistic scenario, exceed this value, biomass power generation systems become feasible.

Quiroz, C. A. B., Gámez, M. R., Borges, C. G. R., \& Rodríguez, J. A. P. (2020). Social implications of biomass-based energy generation in the technical university of Manabí, Ecuador. International Journal of Life Sciences, 4(1), 1-7. https://doi.org/10.29332/ijls.v4n1.386 
On the other hand, energy production from biomass may have more social and environmental implications than a traditional generation (Field et al., 2008; Serna et al., 2011; Carneiro \& Ferreira, 2012). This is due to the conflict in rural areas over land use, the destination of crops towards the supply of generating plants instead of human consumption and the controversial carbon neutrality. However, implications such as this only occur in crop-based, medium and large-scale projects, so a small-scale project based on waste management would not have a considerable impact. However, biomass energy can only be effective if they are accepted and trusted by the majority of the society affected (Upreti, 2004).

Question 3: Do you consider that the Technical University of Manabí helps in the conservation of the environment?

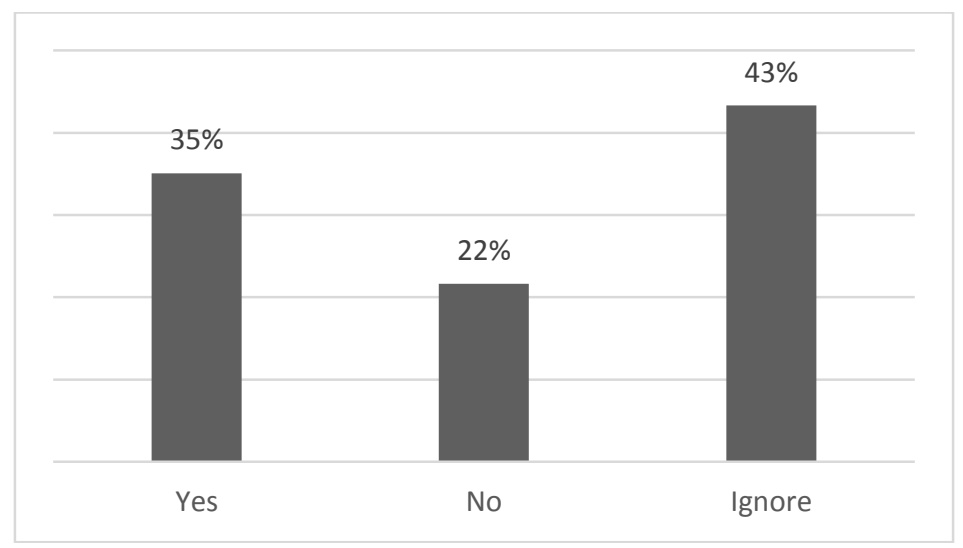

Figure 3. Results of question 3

Figure 3 shows that 35\% of those surveyed (374 people) if they consider that the university helps in the conservation of the environment, 22\% (231 people) responded negatively. Again, the percentage of ignorance is considerable high $(43 \%, 462$ people).

Although the generation of energy from solid organic waste produced on campus could not satisfy the total energy demand of the facilities, it would contribute by efficiently and environmentally friendly disposal of the organic fraction of waste generated.

Question 4: Which of the following aspects makes it more difficult for you to classify solid waste?

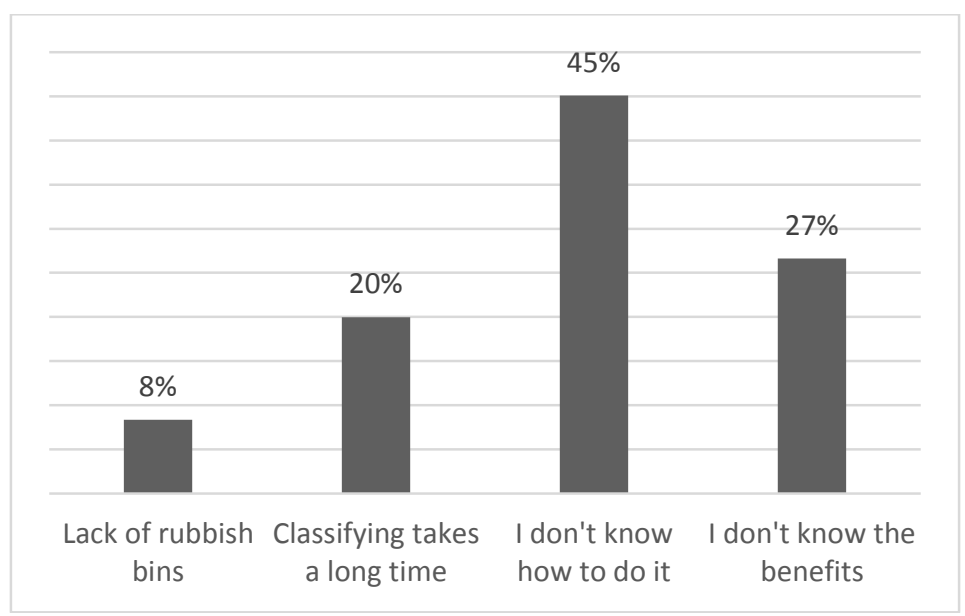

Figure 4. Results of question 4

As can be seen in Figure 4, 45\% (481 people) consider ignorance to be the main limitation for the classification of waste. On the other hand, $27 \%$ (284 people) state that not knowing the benefits of waste 
classification limits people from doing so. In addition, a considerable percentage of people (20\%, 213 people) consider separation to be time-consuming and this limits it. Zhang et al. (2008), consider source separation to be an essential step in reducing the time and cost of any waste treatment or disposal. However, their study revealed that the implementation of a classification system in a community cannot achieve high percentages of accuracy by itself. To maximize separation efficiency, it is necessary to train waste generators. In addition, Zhang et al. (2008), revealed that the active support of the entities in charge plays an important role in improving community participation and awareness of the importance of separation from the source.

Question 5: Which of the following renewable energy sources do you consider most viable for the Technical University of Manabí?

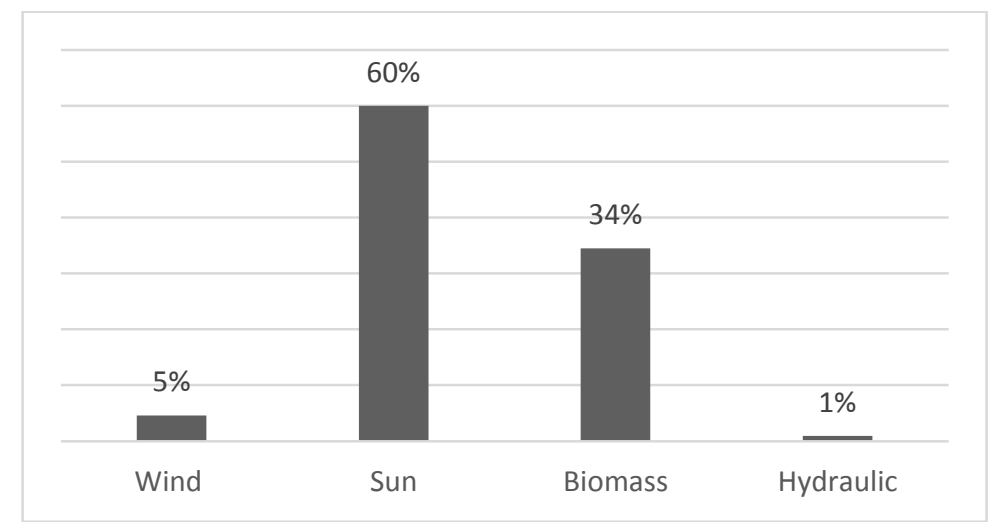

Figure 5. Results of question 5

According to Figure 5, 60\% of those surveyed ( 640 people) consider solar energy to be the most viable energy source for the university, followed by biomass with 34\% (368 people), wind with 5\% (49 people) and hydropower with $1 \%(10)$, despite the fact that there are no potential sources of hydropower near the facilities. Based on the work of Ramos et al. (2018), the university community has an accurate perspective on the renewable sources of energy that the university enjoys. The UTM is located in an area of high solar radiation potential where this resource can be used intensively. Although biomass potential may be overshadowed by solar potential, it is still considerable for use and energy generation.

\section{Conclusion}

Based on results and, in order to guarantee the success of the implementation of an energy generation system based on biomass, it will be necessary to train all those involved in the generation, handling, transport and disposal of solid waste generated in the facilities, i.e. students, teachers, administrative and cleaning personnel, in subjects such as separation, storage, handling of solid waste, among others. It will also be necessary to demonstrate the social and environmental benefits that such a project would bring in order to maximize the acceptance of the university community. However, further studies should study the technical and economic feasibility, and the environmental impacts of implementing a biomass-based generation system, in order to socialize the proposal to the competent authorities and the community.

\section{Acknowledgments}

The authors sincerely appreciate the participation of the students who conducted the survey and all respondents in general for their time and support.

Quiroz, C. A. B., Gámez, M. R., Borges, C. G. R., \& Rodríguez, J. A. P. (2020). Social implications of biomass-based energy generation in the technical university of Manabí, Ecuador. International Journal of Life Sciences, 4(1), 1-7. https://doi.org/10.29332/ijls.v4n1.386 


\section{References}

Carneiro, P., \& Ferreira, P. (2012). The economic, environmental and strategic value of biomass. Renewable Energy, 44, 17-22. https://doi.org/10.1016/j.renene.2011.12.020

Cedeno, M. L. D., Arteaga, M. G. D., Perez, A. V., \& Arteaga, M. L. D. (2017). Regulatory framework for renewable energy sources in Ecuador case study province of Manabi. International Journal of Social Sciences and Humanities, 1(2), 29-42. https://doi.org/10.29332/ijssh.v1n2.33

Chong, T. L., Matsufuji, Y., \& Hassan, M. N. (2005). Implementation of the semi-aerobic landfill system (Fukuoka method) in developing countries: A Malaysia cost analysis. Waste Management, 25(7), 702-711. https://doi.org/10.1016/j.wasman.2005.01.008

Chum, H. L., \& Overend, R. P. (2001). Biomass and renewable fuels. Fuel processing technology, 71(1-3), 187195. https://doi.org/10.1016/S0378-3820(01)00146-1

Duerr, M., Gair, S., Cruden, A., \& McDonald, J. (2007). Hydrogen and electrical energy from organic waste treatment. International journal of hydrogen energy, 32(6), 705-709. https://doi.org/10.1016/j.ijhydene.2006.08.006

Electricity Regulation and Control Agency of Ecuador (ARCE). (2019). National Energy Balance. Retrieved from https://www.regulacionelectrica.gob.ec/balance-nacional/

Field, C. B., Campbell, J. E., \& Lobell, D. B. (2008). Biomass energy: the scale of the potential resource. Trends in ecology \& evolution, 23(2), 65-72. https://doi.org/10.1016/j.tree.2007.12.001

Herout, M., Malaták, J., Kučera, L., \& Dlabaja, T. (2011). Biogas composition depending on the type of plant biomass used. Research in Agricultural Engineering, 57(4), 137-143. https://doi.org/10.17221/41/2010RAE

Intergovernmental Panel on Climate Change (IPCC). (2014). Climate Change 2014: Mitigation of Climate Change. Contribution of Working Group III to the Fifth Assessment Report of the Intergovernmental Panel on Climate Change. Cambridge, United Kingdom and New York, NY, USA: Cambridge University Press. Retrieved from https://www.ipcc.ch/site/assets/uploads/2018/02/ipcc_wg3_ar5_full.pdf

Iván, VR, Melitón, EJ, José, MR, \& Agustina, OS (2015). Potential for generating biogas and electrical energy. Part II: urban solid waste. Engineering, research and technology, 16 (3), 471-478. https://doi.org/10.1016/j.riit.2015.05.012

National Secretary for Planning and Development of Ecuador (SENPLADES). (2017). National Plan for Good Living 2017-2021. Retrieved from https://www.gobiernoelectronico.gob.ec/wpcontent/uploads/downloads/2017/09/Plan-Nacional-para-el-Buen-Vivir-2017-2021.pdf

Perez, A. V., Gamez, M. R., Viteri, C. G. V., \& Quiroz, A. M. V. (2017). Community power as a driving force for sustainable local development. International Research Journal of Engineering, IT \& Scientific Research, 3(4), 8-19.

Quito Municipality (2017). Quito stands out in Ecuador by producing electricity from garbage. Retrieved from http://www.quitoinforma.gob.ec/2017/10/16/quito-se-destaca-en-el-ecuador-al-producir-energiaelectrica-de-la-basura/

Ramos, J. L. M., Pérez, A. V., Gámez, M. R., \& Zambrano, R. V. H. (2018). Renewable energy sources on the change of energy matrix in Manabí province. International research journal of engineering, IT \& scientific research, 4(4), 17-29. https://doi.org/10.21744/irjeis.v4n4.255

Serna, F., Barrera, L., \& Montiel, H. (2011). Impacto social y económico en el uso de biocombustibles. Journal of technology management \& innovation, 6(1), 100-114. https://doi.org/10.4067/S071827242011000100009

Serrano, J., Mejía, W., Ortiz, J., Sánchez, A., \& Zalamea, S. (2017). Determinación del potencial de generación eléctrica a partir de biomasa en el Ecuador.

Spiegel, M. R., \& Stephens, L. J. (2007). Schaum's Outline of Statistics. Schaum's Outline Series.

Upreti, B. R. (2004). Conflict over biomass energy development in the United Kingdom: some observations and lessons from England and Wales. Energy policy,32(6), 785-800. https://doi.org/10.1016/S03014215(02)00342-7

Zhuang, Y., Wu, S. W., Wang, Y. L., Wu, W. X., \& Chen, Y. X. (2008). Source separation of household waste: a case study in China. Waste management, 28(10), 2022-2030. https://doi.org/10.1016/j.wasman.2007.08.012 


\section{Biography of Authors}

\begin{tabular}{|c|c|}
\hline & $\begin{array}{l}\text { Carlos Alejandro Bowen Quiroz is an environmental engineer, focused on } \\
\text { promoting sustainable development, who works in the Department of Industrial } \\
\text { Engineering of the Faculty of Mathematical, Physical and Chemical Sciences of the } \\
\text { Technical University of Manabí. } \\
\text { Email: cabowen@utm.edu.ec }\end{array}$ \\
\hline & $\begin{array}{l}\text { Maria, } \\
\text { Bachelor of Education, Specialty: Physics and Astronomy, MSc. Planning and } \\
\text { Territorial Development (Strategic Planning Renewable sources of energy). Dra. } \\
\text { Strategies and Planning of the territory in Renewable Sources of Energy. } \\
\text { ProfessorResearcher Evaluator of the CYTED and Colciencia program. Evaluator of } \\
\text { the Scielo Ecuador magazines. Expert in Energy Renewable Energy programs. Pair } \\
\text { evaluator of different international magazines. Author of several books, scientific } \\
\text { articles in academic journals, monographs, national and international events, is } \\
\text { directed the project: Una geoweb, for sustainable development in the province of } \\
\text { Manabí, approved in the UTM. } \\
\text { Email: mariarodriguez@utm.edu.ec }\end{array}$ \\
\hline & $\begin{array}{l}\text { Ciaddys Gina, } \\
\text { PhD, Industrial Engineer, Researcher oriented to the study of the theme of energy } \\
\text { efficiency, system for the use of renewable energy sources, studies for the } \\
\text { continuous improvement of administrative and operational processes. With } \\
\text { University Teaching experience of more than } 11 \text { years and in the Venezuelan } \\
\text { electricity company, conducting research projects and talks in conjunction with } \\
\text { the university, industrial and community sectors. } \\
\text { Email: rodriguezciaddy@gmail.com }\end{array}$ \\
\hline & $\begin{array}{l}\text { Jesus Albert, } \\
\text { PhD, Electrical Engineer with more than } 30 \text { years of experience in the design and } \\
\text { development of projects of Lighting and Electrical Channels, Electrical Distribution } \\
\text { Systems; With experience of more than } 30 \text { years as a University Professor and } \\
\text { Researcher, with a focus on data acquisition systems, control, didactic robotics } \\
\text { Email: jesusperez@gmail.com }\end{array}$ \\
\hline
\end{tabular}

Quiroz, C. A. B., Gámez, M. R., Borges, C. G. R., \& Rodríguez, J. A. P. (2020). Social implications of biomass-based energy generation in the technical university of Manabí, Ecuador. International Journal of Life Sciences, 4(1), 1-7. https://doi.org/10.29332/ijls.v4n1.386 